軽金属 第69巻第1号 (2019), 15-21

$$
\begin{aligned}
& \text { アルミニウム材新製造プロセス技術開発 } \\
& \text { 兒島 洋一 }{ }^{1 *} \text {. 津田 哲哉 }{ }^{2} \cdot \text { 宇井 幸 }{ }^{3} \\
& \text { 上田 幹人 }{ }^{4} \text {. 三宅 正男 }{ }^{5}
\end{aligned}
$$

Journal of The Japan Institute of Light Metals, Vol. 69, No. 1 (2019), 15-21

(C) 2019 The Japan Institute of Light Metals

\title{
Development of new production processes for aluminum
}

\author{
Yoichi KOJIMA ${ }^{1 *}$, Tetsuya TSUDA ${ }^{2}$, Koichi UI ${ }^{3}$, \\ Mikito UEDA ${ }^{4}$ and Masao MIYAKE ${ }^{5}$
}

\begin{abstract}
Keywords: aluminum; ionic liquid; smelting
\end{abstract}
\section{1.はじめに}

題目として掲げた「アルミニウム材新製造プロセス技術 開発」は, 新構造材料技術研究組合 (Innovative Structural Materials Association, ISMA）の研究開発体制における「革 新的アルミニウム材の開発」での研究テーマの1つである。 ISMA は経済産業省の委託事業である「未来開拓型研究プロ ジェクト」に位置づけられて平成 23 年に発足し, 平成 24 年 度からは新エネルギー・産業技術総合開発機構（NEDO）の 委託事業として継続されている。本研究テーマはISMA 発足 時にスタートし，目下，6年目を迎えている。ISMA 組合員 である株式会社UACJ と, 再委託先の北海道大学, 岩手大学, 京都大学および大阪大学との産学協業で，基盤技術の確立か ら事業化までを視野に遂行中である。本テーマでは最終目的 を, アルミニウムの製錬法として, 現行のホール・エルー法 よりエネルギー消費量のはるかに少ない革新的製鍊プロセス の開発としている。研究成果の詳細については未だ公表の段 階に至っていないため, 本報では本研究テーマの技術的背景 について解説する。

\section{2. 電 解 液}

アルミニウムの析出電位は水素発生よりもかなり卑 $(-1.66 \mathrm{~V}$ vs. NHE）であるため, 金属アルミニウムを電気化学的に得 ることのできる電解液は必然的に非水系に限られてしまう。 アルミニウム電解製錬で使われているホール・エルー（HallHéroult) プロセスの電解浴（フッ化物系溶融塩（操作温度 が $1000^{\circ} \mathrm{C}$ 程度)）も言うまでもなく非水系である。アルミ ニウムの電気めっきでは, ドイッのSiemens社が開発した $\mathrm{Sigal}^{\circledR}{ }^{\circledR}$ プスが代表的なプロセスとして知られており, 有
機アルミニウム化合物, 芳香族系溶媒, アルカリハライド 塩（またはアルカリ水素化物），4級オ二ウム塩などから構 成される発火性の非水電解液が用いられている。上記のプロ セスはどちらも環境負荷が大きく，これらに代わる低環境負 荷型プロセスの構築が期待されている。これを現実のものと するための鍵となるのが電解液である。その電解液に求めら れる条件として, 室温または室温付近で利用できる, 環境 へ大きなダメージを与える揮発性有機化合物（VOC: Volatile Organic Compounds）を含まない, 難燃性である, 物理化学 安定性が高い, イオン伝導度が高いなどが挙げられる。近 年, 多くの分野で利用されているイオン液体はこれらの条件 を満たす可能性のある唯一の溶媒系と言える。イオン液体に は数多くの種類が存在し, 大気䨌囲気下で利用可能なものも 少なくない ${ }^{1), 2)}$ 。しかしながら, 大気䨌囲気下で安定なイオ ン液体はアルミニウムイオン源として添加するアルミニウム 塩の溶解度が低いため, 高い生産効率を期待することができ ない。以上のような背景から, 本プロジェクトでは取り扱い やすさの点においてやや劣るものの, 豊富な熱力学的データ が存在し, アルミニウム金属析出に寄与するイオン種の濃度 を $3.3 \times 10^{3} \mathrm{molm}^{-3}(3.3 \mathrm{M})$ 程度まで高めることのできる塩化 アルミニウム $\left(\mathrm{AlCl}_{3}\right)$ と1-エチル -3-メチルイミダゾリウム クロライド (1-ethyl-3-methylimidazolium chloride ([EtMeIm] $\mathrm{Cl})$ ）功構成されるイオン液体を標準電解液としている ${ }^{3)}$ 。 [EtMeIm] $\mathrm{Cl}$ を含め, $\mathrm{AlCl}_{3}$ 系イオン液体を構成する代表的 な有機塩の構造式を図 1 に示す。

$\mathrm{AlCl}_{3}$ - $[\mathrm{EtMeIm}] \mathrm{Cl}$ イオン液体はアルミニウム電析の際に 用いられることの多い電解液であり, これまでに数多くの

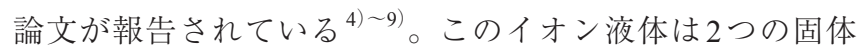
塩を室温で混ぜるだけで液体塩が得られ，その物性は2つ

\footnotetext{
${ }^{1}$ 株式会社UACJ R\&Dセンター（†455-8670 愛知県名古屋市港区千年 3-1-12） Research \& Development Division, UACJ Corporation (3-1-12 Chitose, Minato-ku, Nagoya-shi, Aichi 455-8670)

2 大阪大学大学院工学研究科（吹田市） Graduate School of Engineering, Osaka University (Suita-shi, Osaka)

3 岩手大学理工学部 (盛岡市) Faculty of Science and Engineering, Iwate University (Morioka-shi, Iwate)

${ }^{4}$ 北海道大学大学院工学研究院（札幌市） Faculty of Engineering, Hokkaido University (Sapporo-shi, Hokkaido)

5 京都大学大学院エネルギー科学研究科（京都市） Graduate School of Energy Science, Kyoto University (Kyoto-shi, Kyoto)

*責任著者E-mail: kojima-yoichi@uacj.co.jp

受付日：2018年11月2日＼cjkstart受理日：2018年11月27日
} 
<smiles></smiles>

[Btpy]Cl
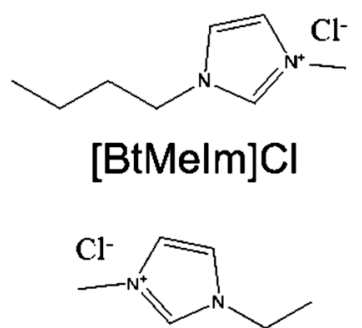

[EtMelm]Cl
図1塩化アルミニウム系イオン液体を構成する代表的 な有機塩の構造式

$\left[\times 10^{+3}\right]$

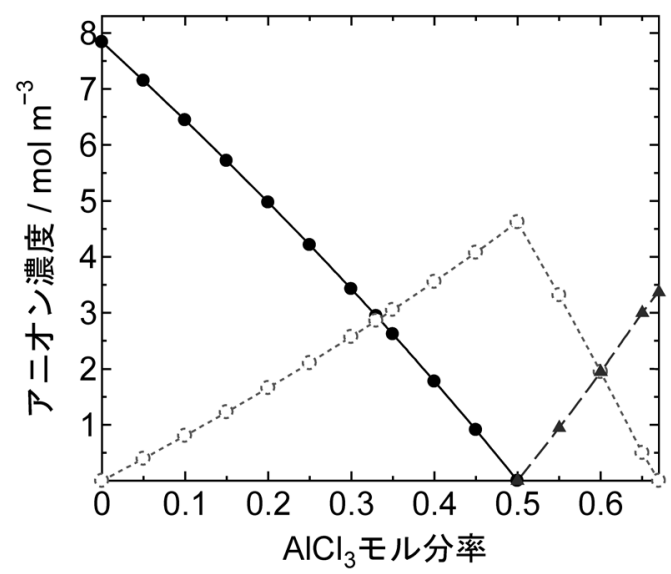

図2 種々の $\mathrm{AlCl}_{3}$ モル分率において $\mathrm{AlCl}_{3}$ - $[\mathrm{EtMeIm}] \mathrm{Cl}$ イオン液体に含まれるアニオン種 $\left(\mathrm{Cl}^{-}, \mathrm{O}\right.$ : $\left.\left[\mathrm{AlCl}_{4}\right]^{-}, \boldsymbol{\Delta}:\left[\mathrm{Al}_{2} \mathrm{Cl}_{7}\right]^{-}\right)$とその濃度の関係

の塩の混合比によって大きく変化する。図2に種々の $\mathrm{AlCl}_{3}$ モル分率におけるアニオン種の存在比を示しているが, こ のイオン液体は $\mathrm{Cl}^{-}$と $\left[\mathrm{AlCl}_{4}\right]^{-}$が共存, $\left[\mathrm{AlCl}_{4}\right]^{-}$のみが存 在, $\left[\mathrm{AlCl}_{4}\right]^{-}$と $\left[\mathrm{Al}_{2} \mathrm{Cl}_{7}\right]^{-}$が共存する3つの領域に大きく分 類することができる。つまり, $\mathrm{AlCl}_{3}$ のモル分率 $\left(N_{\mathrm{AlCl}_{3}}\right)$ が $0<N_{\mathrm{AlCl}_{3}}<0.50$ (ルイス塩基性), $N_{\mathrm{AlCl}_{3}}=0.50$ (ルイス中性), $0.50<N_{\mathrm{AlCl}_{3}} \leq 0.67$ (ルイス酸性) の3つの領域である。 $\mathrm{AlCl}_{3}$ のモル分率によって, イオン液体を構成するイオン種やその 組成は大きく変化することから，それに伴い，このイオン液 体の物理化学的性質も大きく変化する。このイオン液体系で の金属アルミニウムの析出は $\left[\mathrm{Al}_{2} \mathrm{Cl}_{7}\right]^{-}$の還元反応によって のみ起こるため, アルミニウム電析には $N_{\mathrm{AlCl}_{3}}$ が $0.50<N_{\mathrm{AlCl}_{3}} \leq$ 0.67 の範囲にあるルイス酸性浴を用いる必要がある。このと きのアルミニウム析出・溶解反応は以下のようであり, 適切 な電解条件を用いれば，その電流効率は $100 \%$ に近い值とな る。

$$
4\left[\mathrm{Al}_{2} \mathrm{Cl}_{7}\right]^{-}+3 \mathrm{e}^{-} \rightleftarrows \mathrm{Al}+7\left[\mathrm{AlCl}_{4}\right]^{-}
$$

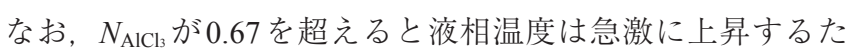
め, この領域が研究対象となることはほとんどない。

ルイス酸性 $\mathrm{AlCl}_{3}$ - $[\mathrm{EtMeIm}] \mathrm{Cl}$ を電解液に用いると, 後述 するように良好なアルミニウムめっき膜を得ることができる

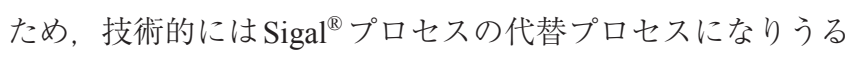
レベルに到達している。しかし，その実用化を阻む最も大き
な要因になっているのが $[\mathrm{EtMeIm}] \mathrm{Cl}$ の合成コストであり, その課題をクリアするためのアプローチも本プロジェクトの 検討課題の 1 つなっている。ここでは $\mathrm{AlCl}_{3}-[\mathrm{EtMeIm}] \mathrm{Cl}$ に 代わる電解液の探索の現状について紹介する。これまでに報

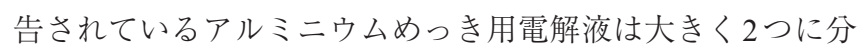
類することができる。1つは $[\mathrm{EtMeIm}] \mathrm{Cl}$ よりも安価な塩を 用いたイオン液体・溶融塩の合成であり, 古くから行われて いる。カチオンの種類は組み合わせる塩の種類によって変化 するものの, アルミニウムの電析プロセスに関与するアニオ ン種は $\mathrm{AlCl}_{3}-[\mathrm{EtMeIm}] \mathrm{Cl}$ 系と基本的に同じであるため, ア ルミニウムの電析反応自体に変化はない。これに対し, 尿素 やジメチルスルホン, グライム, 1,3-ジメチル-2-イミダゾ リジノン，4-プロピルピリジンなどの極性有機分子（Base） と $\mathrm{AlCl}_{3}$ を混合した系は溶媒和イオン液体, Deep Eutectic Solvent（DES）などと呼ばれ, 近年, アルミニウムめっき用 電解液として注目されている。これらの電解液では次の反応 式(2)または（3）によって2種類のアルミニウムイオンが 得られ ${ }^{9) \sim 11)}$, 生成したアルミニウム錯カチオンをアルミニ ウム電解に利用した研究も多く存在する。

$$
\begin{aligned}
& 2 \mathrm{AlCl}_{3}+n \text { Base } \rightleftarrows\left[\mathrm{AlCl}_{2} \cdot n \text { Base }\right]^{+}+\left[\mathrm{AlCl}_{4}\right]^{-} \\
& 4 \mathrm{AlCl}_{3}+n \text { Base } \rightleftarrows\left[\mathrm{Al}(\text { Base })_{3}\right]^{3+}+3\left[\mathrm{AlCl}_{4}\right]^{-}
\end{aligned}
$$

アルミニウムの析出に関与するイオン種が (1)式とは異なる ため, これが析出物の形態や電流効率に与える影響について は, より詳細に検討する必要がある。また, フリーな極性分 子が存在する組成域においては, これが電解液の物性や電析 物に与える影響についても考慮する必要がある。逆に $\mathrm{AlCl}_{3}$ が過剩量存在する組成域では, $\left[\mathrm{AlCl}_{4}\right]^{-}$との反応によって, $\left[\mathrm{Al}_{2} \mathrm{Cl}_{7}\right]^{-}$が生成するため（(4)式），そのような条件下におい ては, 前述の $\mathrm{AlCl}_{3}$ 系イオン液体や溶融塩系と同様, (1) 式に よるアルミニウムの析出・溶解反応が進行する。

$$
\left[\mathrm{AlCl}_{4}\right]^{-}+\mathrm{AlCl}_{3} \rightleftarrows\left[\mathrm{Al}_{2} \mathrm{Cl}_{7}\right]^{-}
$$

電解液のコストはどちらの系においても $\mathrm{AlCl}_{3}-[\mathrm{EtMeIm}] \mathrm{Cl}$ 系と比較して，5分の 1 以下に抑えることができるが, 現 時点ではハンドリングの容易性や物性の面において $\mathrm{AlCl}_{3}-$ $[\mathrm{EtMeIm}] \mathrm{Cl}$ 系には及ばず，更なる研究開発が望まれる。

\section{3. 電析条件と表面形態の関係}

電析条件は電析物の結晶構造および表面形態に影響を及 ぼす。一般的な電析条件として, 電流密度, 過電圧, 温度, 擋汼, 反応イオン種の濃度, および添加剂などが挙げられ る ${ }^{12)}$ 。これらを適宜組み合わせて, 目的とする電析物を得 ることになる。例えば, $\mathrm{Li} ら は \mathrm{AlCl}_{3}-[\mathrm{EtMeIm}] \mathrm{Cl}$ 浴を用い る定電流パルス電解において, 電析浴の浴温が上昇すると, 電析物の結晶粒の大きさのみではなく, 結晶形態も変化する ことを報告している ${ }^{13)}$ 。

アルミニウムの電析物の機能化を目的として, 様々な研究 がなされてきた。その中でも, 表面の平滑化に着目した研 究が四半世紀前からなされてきたので，いくつかを紹介す る。通常, 電析物の平滑性には結晶粒の大きさが関係し, 結 晶粒が小さければ, 平滑性の良好な電析物が得られると考え られる。 $\mathrm{AlCl}_{3}-[\mathrm{EtMeIm}] \mathrm{Cl}$ 浴を用いるアルミニウム電析で 
もこの傾向がみられ，Bakkarらは定電位電解において，電 析物の結晶粒および結晶子径が過電圧に依存し，過電圧が大 きいほど結晶粒および結晶子径は小さくなることを報告して いる ${ }^{14)}$ 。そのため, より卑な電位をかけて電解することで, 平滑な電析物が得られるものと考えられる。

有機系カチオンを含むイオン液体を用いるアルミニウムの 電析の場合, 後述する無機系溶融塩とは異なり, 皮膜の厚さ が $10 \mu \mathrm{m}$ 以下では，表面の凹凸もそれほど問題とならないが, 皮膜の厚さがより厚くなると凹凸が激しくなる ${ }^{15), 16) 。 そ こ ~}$ で，平滑性を向上させることを目的として，電析浴に添加剤 を加えることが検討されてきた。電析浴（めっき浴）に添加 剂を加える目的は，(1)電析物（めっき膜）の均一電着性の改 善，(2)樹枝状晶の防止，(3)平滑化，(4)光沢化，(5)結晶粒の微 細化, (6)残留応力の低減, (7)ピット防止などであり，特に (1)〜(3)の効果のあるものを平滑剤, (4)〜 (6)の効果のあるもの を光沢剂と呼ぶ ${ }^{17)}$ 。通常, 溶融塩電解における添加郕は一 般的に無機物が用いられるが，常温で溶融するイオン液体に は有機溶媒を使用できる。有機溶媒には多種多様のものがあ るが，アルコール，ケトン類はイオン液体と反応するため適 切ではない ${ }^{15)}$ 。有機溶媒添加の一例として, 高橋らは1,10フェナントロリン（図3, 以下，OPと略す）を微量添加す ることで，電析物表面の平滑化が可能であることを報告して いる ${ }^{15), 16)}$ 。さらに, 上田らは $\mathrm{AlCl}_{3}-[\mathrm{EtMeIm}] \mathrm{Cl}$ 浴を用いる<smiles>c1cnc2c(c1)ccc1cccnc12</smiles>

図３１,10-フェナントロリン（OP）の構造式
定電流パルス電解において, OP 添加浴の擋拌速度が平滑性 に影響を及ぼし，無擋拌下では算術平均粗さ（Ra）の值が 約 $26 \mathrm{~nm}$ であったのに対し，擋拌速度の上昇に伴い，電析物 の表面の凹凸が徐々に小さくなり，400 rpmにおける表面の $\mathrm{Ra}$ は $2.3 \mathrm{~nm}$ であったと報告している $(\text { 図4 })^{18)}$ 。

さらに，イオン液体に添加剤を加えることで，電析物のあ る特定の結晶面が優先的に成長する，優先配向が報告されて いる。アルミニウムの配向電析に関する報告例として, 高橋 らが $\mathrm{AlCl}_{3}$ と 1-ブチルピリジニウムクロライド (1- butylpyridinium chloride $([\mathrm{BtPy}] \mathrm{Cl}))$ から構成される $\mathrm{AlCl}_{3}-[\mathrm{BtPy}] \mathrm{Cl}$ イオン液体にベンゼンやトルエンを混合することにより，電 析物の表面状態を制御でき，しかも面配向できることを見出 している ${ }^{19)}$ 。その後, Husseyらもベンゼンを $\mathrm{AlCl}_{3}$ - [EtMeIm] $\mathrm{Cl}$ 浴に混合し,（110）面への配向度が2.0〜3.25に優先配向 した電析物を得ている ${ }^{20)}$ 。一方，津田らは環境負荷を考慮 して，有機溶媒ではなく $\mathrm{LaCl}_{3}$ を $\mathrm{AlCl}_{3}-[\mathrm{EtMeIm}] \mathrm{Cl}$ 浴に混合

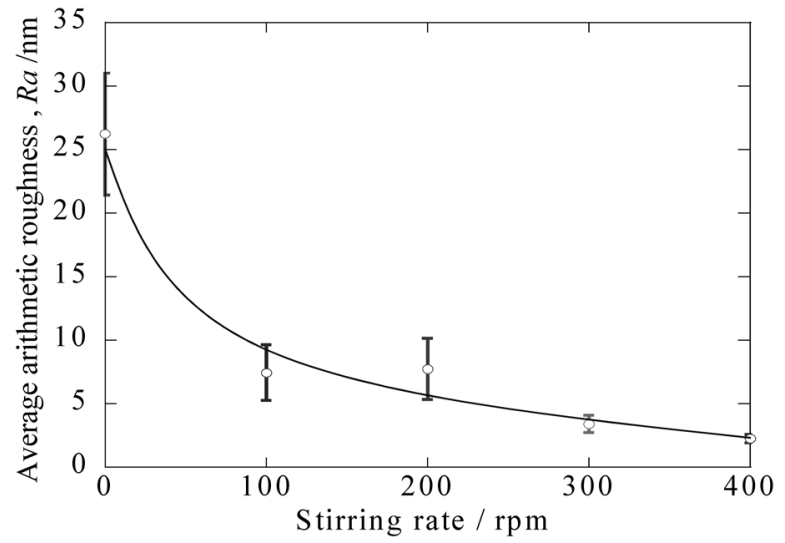

図4 摚挥速度とアルミニウム電析物表面の算術平均粗 さの関係 ${ }^{18}$
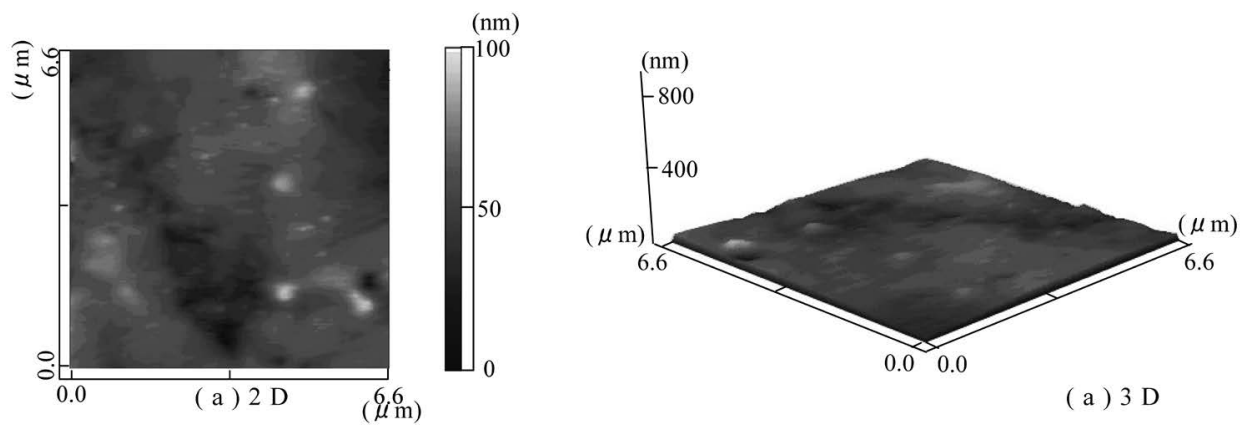

( a ) $3 \mathrm{D}$
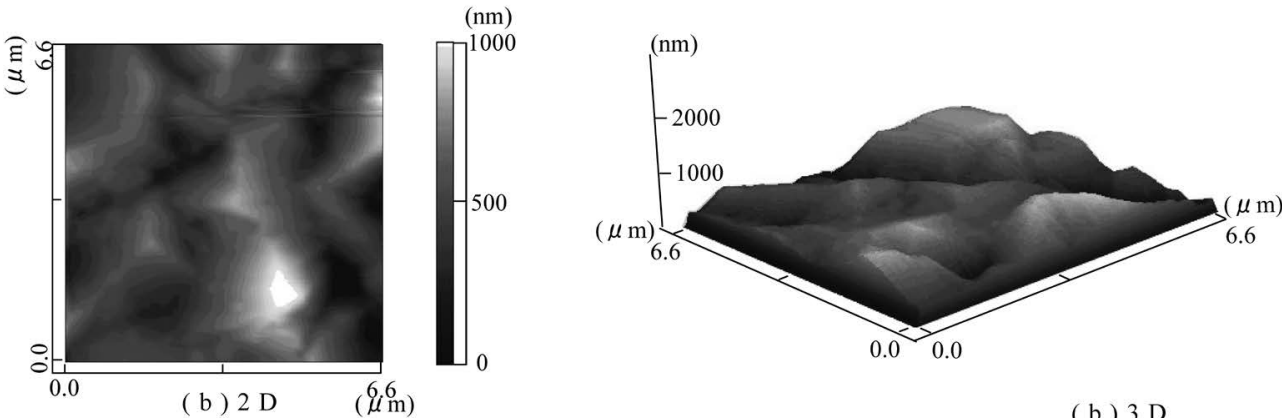

( b ) $3 \mathrm{D}$

図 5 アルミニウム電析物表面の $\mathrm{AFM}$ 像 ${ }^{23)}$ 電流密度 $10 \mathrm{mAcm}^{-2}$, 電析量 $50 \mathrm{C} \mathrm{cm}^{-2}$

(a) $50.0 \mathrm{~mol} \% \mathrm{~m}$-xylene- $33.3 \mathrm{~mol} \% \mathrm{AlCl}_{3}-16.7 \mathrm{~mol} \%[\mathrm{EtMeIm}] \mathrm{Cl}$ 浴,

(b) $50.0 \mathrm{~mol} \%$ p-xylene- $33.3 \mathrm{~mol} \% \mathrm{AlCl}_{3}-16.7 \mathrm{~mol} \%[\mathrm{EtMeIm}] \mathrm{Cl}$ 浴 
し,（100）面への配向度が $2 \sim 2.5$ 程度に優先配向した電析物 を得ている ${ }^{21)}$ 。

宇井らも，混合する芳香族化合物の種類がその配向性に 及ぼす影響を検討してきた。トルエンを混合した浴からの アルミニウムの電析では, (100) 面への配向度が 4 程度に 優先配向する ${ }^{22)}$ 。また, キシレン $(o-, m-, p-)$ 異性体を混 合した浴からの $\mathrm{Al}$ の電析では，すべてのキシレン異性体に おいて，(110）面へ優先配向し，しかも混合率の増加に伴 い, (110) 面への配向が強まる傾向がみられた ${ }^{23)}$ 。しかし, $m$ キシレン混合浴は他の異性体とは異なり， $50 \mathrm{~mol} \%$ 混合浴の み, 金属光沢を有する (100) 面に配向した電析物が得られた。 AFMを用いて，それらの電析物の表面を観察した（図5）。 金属光沢を有する電析物の表面（図 $5(\mathrm{a})$ ) の最大高低差は $100 \mathrm{~nm}$ 程度であったのに対し, 金属光沢を示さない電析物の 表面（図 5(b)）の最大高低差が $1000 \mathrm{~nm}$ であった。このよう に, 有機溶媒を混合すると, 電析浴の粘度が低下するので, 操作性が向上するとともに, 配向性が変化するのみならず, 平滑な電析物が得られやすくなる利点を発現する。

平滑剤による平滑化機構は, 主として反応イオン種の拡散 の制御によるものである ${ }^{17)}$ 。他の電析条件も含めて，電析 機構との関係を明らかにできれば，平滑性のみならず，より 高付加価值をもつ電析物を見出せると考えられる。

\section{4. アルミニウム合金電析}

前述のアルミニウムの電析では，その電析アルミニウムの 耐食性や硬さは，圧延されたアルミニウムや鋳造されたアル ミニウムと大きく違うことはないものと予想される。しかし アルミニウム合金を考えると，その特性は合金添加元素に よって大きく変化することになる。

電析法によるアルミニウム合金の形成では, $\mathrm{AlCl}_{3}$ 含有の イオン液体, ジメチルスルホン $\left(\mathrm{DMSO}_{2}\right)-\mathrm{AlCl}_{3}$ 系, $\mathrm{AlCl}_{3}-$ $\mathrm{NaCl}$ 系溶融塩を電解液として用い, この中に添加合金元素 源となる金属の塩を溶解させて共電析している。この際，合 金系は二元系が一般的であり，三元系合金の電解による組成 制御は容易ではなく報告例は少ない。以下に各種電解液を用 いてのアルミニウム合金を電析した研究を紹介する。

イオン液体を用いたアルミニウム合金めっきについての報 告は, 例えば1990年以降の $\mathrm{Al}-\mathrm{Cr}^{24), 25)}, \mathrm{Al}-\mathrm{Mn}^{26), 27)}, \mathrm{Al}-$ $\mathrm{Ti}^{28)}$ そして $\mathrm{Al}-\mathrm{V}$ 合金 ${ }^{29)}$ などの報告があるが, ここではまず アルミニウムの耐孔食性の改善に着目した津田らの Al-Hf, $\mathrm{Al}-\mathrm{W}, \mathrm{Al}-\mathrm{Zr}, \quad \mathrm{Al}-\mathrm{W}-\mathrm{Mn}$, およびAl-Mo-Tiの合金系の電析 について紹介したい ${ }^{30) \sim 34)}$ 。電解液は $\mathrm{AlCl}_{3}$ - [EtMeIm $] \mathrm{Cl}$ イオ ン液体を用い, この中に各種金属塩を溶解させて電析層を形 成している。Al-Hf合金の電析では，定電流電解によって各 種組成の Al-Hf合金が得られ，XRD測定から金属間化合物 の形成はなく，アルミニウムのマトリックスにHfが固溶し ていると報告している。また，この Al-Hf合金の孔食電位測 定について $0.1 \mathrm{M}$ の $\mathrm{NaCl}$ 溶液中において, 純アルミニウムよ りも最大で約 $0.2 \mathrm{~V}$ 貴な電位までシフトすることが示されて いる。 $\mathrm{A} 1-\mathrm{W}$ 合金の電析では, アルミニウム参照電極に対し -0.05〜0.4Vの範囲で定電位電解を行った結果, ほほアアルミ ニウムのみの電析物から W が 96 at $\%$ 含まれる $\mathrm{Al}-\mathrm{W}$ 合金を得 ている。Al-W 合金の孔食電位測定では, 97.7 at $\% A 1-W$ 合金 の時に純アルミニウムよりも $0.3 \mathrm{~V}$ 貴側にシフトすると報告
している。Al-Zr合金では, 定電流電解によって 1.4 16.6 at $\%$ の $\mathrm{Zr}$ 濃度の $\mathrm{Al}-\mathrm{Zr}$ 合金が得られ, $10 \mathrm{at} \%$ 以上の $\mathrm{Zr}$ 濃度におい て, 純アルミニウムの時よりも孔食電位が約 $0.3 \mathrm{~V}$ 貴側にシ フトすることを報告している。アルミニウムを含む三元系合 金については, 孔食電位測定に着目して紹介すると, Al-WMn 合金では, 89.3 at $\% \mathrm{Al}-6.1 \% \mathrm{~W}-4.6 \% \mathrm{Mn}$ 合金のときに純ア ルミニウムよりも $0.43 \mathrm{~V}$ 貴側にシフトし, Al-Mo-Ti合金で は, 92.4 at $\% \mathrm{Al}-9.0 \% \mathrm{Mo}-0.7 \% \mathrm{Ti}$ 合金が最も貴な電位で合金 の溶解が始まっており, 測定結果からは, 約 $0.4 \mathrm{~V}$ 貴な電位 へのシフトと読み取れる。津田らは以上のように, 二元系合 金よりも三元系合金にすることで耐孔食性がさらに改善され る結果を示している。

このほかにマグネシウム合金の表面処理として S. J. Pan ら がAZ91D合金上に Al-Zn合金のめっきを試みている。この めっきは $\mathrm{AlCl}_{3}-[\mathrm{EtMeIm}] \mathrm{Cl}$ イオン液体中に $\mathrm{ZnCl}_{2}$ を添加し, 定電位電解によって形成されている ${ }^{35)}$ 。亜鉛はアルミニウム よりも貴な金属であるので, 電解の電位がより貴になるのに 伴い亜鉛の含有割合が増加する。各種電位で形成されためっ き膜の断面SEM像からは, アルミニウム参照電極に対して $-0.2 \mathrm{~V}$ の電位で形成された $\mathrm{Al}-\mathrm{Zn}$ 合金めっきは下地のマグネ シウムとの密着性があまりよくなく, $-0.4 \mathrm{~V} て ゙$ 形成されたも のの方がより密着しためっき膜になっている。

$\mathrm{DMSO}_{2}-\mathrm{AlCl}_{3}$ 電解液を用いた研究では, 三宅らの報告で ジンケート処理後の $\mathrm{AZ} 61$ 合金上に $\mathrm{DMSO}_{2}$ と $\mathrm{AlCl}_{3}$ からな る有機系電解液を用いて $110^{\circ} \mathrm{C}$ で $\mathrm{Al}-\mathrm{Zn}-\mathrm{Mg}$ 合金層を形成し た報告がある ${ }^{36)}$ ○のアルミニウム層は断面 SEM像より， $20 \mu \mathrm{m}$ 程度の緻密でフラットなものであった。また，塩見ら は $\mathrm{DMSO}_{2}-\mathrm{AlCl}_{3}$ 電解液に $\mathrm{ZrCl}_{4}$ を添加して $\mathrm{Al}-\mathrm{Zr}$ 合金を電析 しており, 電解液中の $\mathrm{ZrCl}_{4}$ 量によって光沢になる条件と光 沢にならない条件があることを報告している ${ }^{37)}$ この $\mathrm{Al}-\mathrm{Zr}$ 合金めっきに対して $0.1 \mathrm{MNaCl}$ 水溶液中で孔食電位を調べた 結果, Al-3.5 at $\% \mathrm{Zr}$ 合金における孔食電位は, 純アルミニウ ムのときよりも $0.15 \mathrm{~V}$ 貴側にシフトする結果であった。この 組成における電位シフトは, イオン液体を用いて形成した津 田らの結果に近いものになっている。

溶融塩系によるアルミニウム合金の電析では, $\mathrm{AlCl}_{3}-\mathrm{NaCl}$ 系と $\mathrm{AlCl}_{3}-\mathrm{NaCl}-\mathrm{KCl}$ 系の溶融塩を用いた報告がある。上田 らは $\mathrm{AlCl}_{3}-\mathrm{NaCl}-\mathrm{KCl}$ 溶融塩を用いて各種組成の $\mathrm{Al}-\mathrm{Zr}$ 合金 を電析し $0.1 \mathrm{MNaCl}$ 水溶液中において孔食電位を調べてい $ろ^{38)}$ 。Al-23at $\% \mathrm{Zr}$ 合金の際の孔食電位は純アルミニウムよ

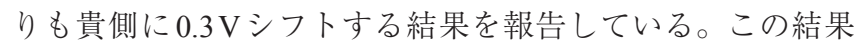
は, イオン液体を用いての $\mathrm{Al}-\mathrm{Zr}$ 合金の值とも近く, $\mathrm{Al}-\mathrm{Zr}$ 合金系に関しては, 各種電解液で形成することが可能で, そ れらの組成では耐孔食性も近いものになると考えられる。

また, 上田らは $\mathrm{AlCl}_{3}-\mathrm{NaCl}-\mathrm{KCl}$ 溶融塩への $\mathrm{PtCl}_{2}$ 添加に よる Al-Pt 合金の電析 ${ }^{39)}, \mathrm{SnCl}_{2}$ 添加による Al-Sn 合金の電 析 ${ }^{40)}, \mathrm{TaCl}_{5}$ 添加による $\mathrm{Al}-\mathrm{Ta}$ 合金の電析 ${ }^{41)}$ についても報 告している。Al-Cr合金の電析に関しては, Moffat ${ }^{24)}$, 松 永ら $^{42)}$ や上田らによる報告がある ${ }^{43)}$ 。 $\mathrm{Al}-\mathrm{Mn}$ 合金では, Staffordがガラス状の Al-Mn 合金が得られることを報告し ており ${ }^{44)}$, 大きな規模での Al-Mn合金めっきとして内田 らの報告がある ${ }^{45)}$ 。 $\mathrm{Al}-\mathrm{Ti}$ 合金では, 内田らは $\mathrm{Ti}$ 含有量 が $40 \mathrm{mass} \%$ の $\mathrm{Al}-\mathrm{Ti}$ 合金の平滑電析について報告をしてい る ${ }^{46)}$ 。 
三元系合金の電析については, 上田らが $\mathrm{AlCl}_{3}-\mathrm{NaCl}-\mathrm{KCl}$ 溶融塩に $\mathrm{CrCl}_{2}$ と $\mathrm{NiCl}_{2}$ を溶解させ, $\mathrm{Al}-\mathrm{Cr}-\mathrm{Ni}$ 合金を電析さ せた報告がある。合金組成の制御は，定電位電解では限界が あるため, 電析物の一部を溶解させるような電位パルス電解 によって，各種成分の濃度をある程度変化させることができ るとしている ${ }^{47)}$ 。

以上のようにアルミニウム膜を電解で形成するには，電解 液と電極と直流電源があれば可能であり，比較的安価にでき るものである。合金系を考えると高融点系のものや非平衡な ものも室温から $100^{\circ} \mathrm{C}$ 程度で電析させることができるため, 今後さらに発展するものと考えられる。

\section{5. アルミニウム電析の応用展開}

上述のアルミニウム電析の応用技術が，めっき分野に留ま らず，様々な分野で研究されている。ここでは，アルミニウ ム電析の応用例として，アルミニウム箔の製造，マイクロ・ ナノ構造体の形成, および電解精錬の研究開発について紹介 する。

\section{1 アルミニウム箔の製造}

リチウムイオン電池の正極集電体としてアルミニウム箔が 使用されている。電池の小型化や高容量化のニーズが年々高 まっており，これに応えるため，アルミニウム箔をさらに薄 箔化することが求められている。現在，アルミニウム箔は, 圧延によって製造されているが，薄䇴の製造では圧延工程の 回数を多くする必要があるため，コストが割高になる問題が ある。圧延に代わるアルミニウム䇴の製造法として，電析法 の利用が考えられる。古くから工業利用されている電解銅箔 の製造プロセスと同様の原理により，アルミニウム箔につい ても，基材上に電析させたアルミニウム膜を剥離することで 製造することができる。

日立金属株式会社の岡本らは, $\mathrm{DMSO}_{2}-\mathrm{AlCl}_{3}$ 電解液に添 加剤としてトリメチルアミン塩酸塩を加えた浴を用い, チ夕 ン板上にアルミニウムを電析させ，そのアルミニウム膜を基 板から引き剥がすことで，厚さ $8 \sim 30 \mu \mathrm{m}$ のアルミニウム箔 が作製可能であることを報告している ${ }^{48)}$ 。圧延によって得 られるアルミニウム箔は, 箔面に平行な方向に引き伸ばされ た結晶組織をもつのに対して，電解アルミニウム箔では，箔 面垂直方向に成長した柱状結晶が並ぶ組織となる。引張強度 やその温度安定性を評価すると，電解アルミニウム箔は，従 来の圧延箔に比べて，優れた特性を示したことが報告されて いる。電解アルミニウム箔のリチウムイオン電池の正極集電 体としての適正についての評価も行われており，電解アルミ ニウム箔がもつ表面の微細な凹凸形状や優れた濡れ性が，集 電体用途において優位に作用することが報告されている ${ }^{49)} 。$ $\mathrm{AlCl}_{3}-[\mathrm{EtMeIm}] \mathrm{Cl}$ イオン液体を用いても, 同様に電解アル ミニウム箔を得ることができる。

\section{2 マイクロ・ナノ構造体の形成}

アルミニウム電析を利用すると, アルミニウム薄膜だけで なく，金属アルミニウムからなる様々なマイクロ・ナノ構造 体を形成することができる。マイクロ・ナノ構造体の形成に おいては，多くの場合，目的の構造のテンプレート（鋳型） を用い，その内部にアルミニウムを電析した後，テンプレー 卜を除去することで，アルミニウムからなる構造体を得る方 法が採られる。テンプレートの空隙が大きい場合には，アル ミニウムの溶湯を流しこむことも可能であるが，孔径がミク ロンオーダー以下になると, 表面張力の関係から, テンプ レートの空隙を溶湯で充填することは困難である。しかし， 電析法を用いれば, 複雑な細孔内にもアルミニウムを析出さ せることができる。

多数の細孔が直線状に貫通するメンブレンをテンプレート に用い, その中にアルミニウムを電析した後，テンプレー トを除去すれば, アルミニウムのナノロッドまたはナノワ イヤーが得られる。基板上にアルミナ・メンブレンを載せ, $\mathrm{AlCl}_{3}-[\mathrm{EtMeIm}] \mathrm{Cl}$ イオン液体を用いてアルミニウム電析を 行うと，メンブレンの細孔内にアルミニウムが成長し，その 後，アルミナ・メンブレンをリン酸とクロム酸を使って溶解 除去すれば，アルミニウムのナノロッドが得られる ${ }^{50) ５ 2)}$ 。 ナノロッドの径はメンブレンの孔径によって制御が可能であ り，最小で $40 \mathrm{~nm}$ 程度の径のナノロッドの形成が報告されて いる。同様のナノロッドまたはナノワイヤーは, ポリカーボ ネート・メンブレンをテンプレートに用いても形成すること ができる ${ }^{53)}$,54)。ポリカーボネートは, ジクロロメタンによっ て溶解除去可能である。

アルミニウムナノワイヤーについては, $\mathrm{AlCl}_{3}$-トリメチル アミン塩酸塩浴を用い, テンプレートを使わず，電析によっ て直接形成する方法も報告されている ${ }^{55)}$,56)。

直線状の細孔内にだけでなく，三次元的な複雑な形状をも つ細孔内にアルミニウムを電析することも可能であり，これ により，アルミニウム多孔体を形成する研究も行われてい る。Endresらは，ポリスチレン・コロイド粒子の自己組織化 によって形成されるコロイド結晶をテンプレートとして用 い, この空隙内に $\mathrm{AlCl}_{3}-[\mathrm{EtMeIm}] \mathrm{Cl}$ イオン液体を用いてア ルミニウムを電析し, その後, 有機溶剤によってコロイド結 晶テンプレートを溶解除去することで，アルミニウム多孔 体が得られることを報告している ${ }^{57)}$ 。この方法により，径 $600 \mathrm{~nm}$ 程度の空孔が三次元的に連通する構造をもつアルミ ニウム多孔体が得られている。

住友電気工業株式会社では, 従来から, ニッケルの多孔体 を製造, 販売している。このニッケル多孔体は, 導電化処理 を施したウレタン発泡体にニッケルめっきを施し，その後， ウレタン発泡体を熱分解除去するプロセスにより製造されて いる。同様のプロセスを用い, ニッケルめっきの代わりに, $\mathrm{AlCl}_{3}-[\mathrm{EtMeIm}] \mathrm{Cl}$ イオン液体を用いてアルミニウムを電析

表 $1 \mathrm{Al}-\mathrm{SiC}$ 複合材アノードおよびカソード電析物の組成 $(\operatorname{mass} \%)^{62}$

\begin{tabular}{l|c|c|c|c|c|c|c|c}
\hline \hline & $\mathrm{Al}$ & $\mathrm{SiC}$ & $\mathrm{Si}$ & $\mathrm{Cu}$ & $\mathrm{Fe}$ & $\mathrm{Zn}$ & $\mathrm{Mg}$ & $\mathrm{Ni}$ \\
\hline $\mathrm{Al}-\mathrm{SiC}$ 複合材アノード & 66.22 & 23 & 5.78 & 2.31 & 1.05 & 0.77 & 0.38 & 0.1 \\
\hline カソード電析物 & 98.15 & - & - & 1.26 & 0.04 & 0.31 & 0.13 & 0.1 \\
\hline
\end{tabular}


することで, 平均孔径 450 900 $\mu \mathrm{m}$, 気孔率 $95 \%$ 程度のアル ミニウムの多孔体が得られることが示されている ${ }^{58), 59) 。 ~}$

以上に述べた様々な形状のアルミニウムマイクロ・ナノ構 造体は, 主に, リチウムイオン電池の電極または集電体とし ての応用が検討されている。電析を利用することで, 多様な 形状のマイクロ・ナノ構造体の形成が可能であり，今後，よ り広範な用途への応用が期待される。

\section{3 電解精錬}

イオン液体を用いたアルミニウムの電解精錬が検討され ている。Reddyらは, Al-Si-Mg系合金またはAl-SiC 複合材 のスクラップをアノードに用いて電解を行うことで，高純 度のアルミニウムをカソード上に析出させる試みを報告し

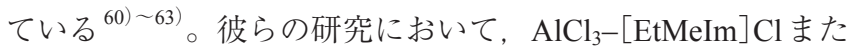
は $\mathrm{AlCl}_{3}$ と 1-ブチル -3-メチルイミダゾリウムクロライド（1butyl-3-methylimidazolium chloride $([\mathrm{BtMeIm}] \mathrm{Cl}))$ から構成さ れる $\mathrm{AlCl}_{3}-[\mathrm{BtMeIm}] \mathrm{Cl}$ イオン液体が電解液に用いられ, 約 $100^{\circ} \mathrm{C}$ の温度で電解が行われている。スクラップには， シ リコン，銅，覀鉛，鉄，マグネシウムなどの不純物が含ま れるが, これらの不純物濃度が大幅に低減されたアルミニ ウムがカソード上に電析されることが確認されている。一 例として， $\mathrm{Al}-\mathrm{SiC}$ 複合材をアノードに用いて電解を行った 結果, 得られたアルミニウム電析物の組成 ${ }^{62)}$ を, 電解前の $\mathrm{Al}-\mathrm{SiC}$ 複合材の組成とともに表 1 に示す。彼らの報告によれ ば, この電解の消費電力量はアルミニウム $1 \mathrm{~kg}$ の製造あたり 約 $5 \mathrm{kWh}$ と見積もられており, 現在広く行われている温度 $800 \sim 950^{\circ} \mathrm{C}$ での三層式溶融塩電解のエネルギー消費量 15 $18 \mathrm{kWh}$ と比べて大幅に少ない。イオン液体を用いる電解で は, 操業温度が低いことが, エネルギー消費量の低減の要因 と考えられる。

\section{6. おわりに}

各種金属の水溶液からの電解析出・めっき技術は19世紀 後半から発展してきた。しかしながらアルミニウムについて は, その析出電位が水素発生よりもかなり卑であるため, こ うした発展の蚊帳の外にあった。1980年頃になってイオン 液体を用いたアルミニウムの電解析出に関する公知文献が増 え始めてからは，関連技術は発展著しく，活況を呈した。軽 金属学会においても, 平成 23 年から 26 年にかけて, 研究部 会でこうした技術の調査検討を実施した ${ }^{64)}$ 。本報に詳述し たとおり，イオン液体を用いた電解プロセス技術はアルミニ ウム産業にとって多くの魅力的な可能性を秘めている。それ らの具現化, 事業化を目指し, 著者一同, 今後も「アルミニ ウム材新製造プロセス技術開発」の完遂に取組む所存である ことを最後に記し，本稿を終えることとする。

謝 辞

「アルミニウム材新製造プロセス技術開発」は, 国立研究 開発法人新エネルギー・産業技術総合開発機構（NEDO）の 委託業務として実施中であることを付記し，謝意を表する。

\section{参 考 文 献}

1) P. Wasserscheid and T. Welton: Ionic Liquids in Synthesis, Second Edition, ed.by Wiley-VCH Verlag GmbH, Weinheim (2008).

2) F. Endres, A. Abbott and D. MacFarlane: Electrodeposition from Ionic Liquids, Second, Completely Revised and Enlarged Edition, ed.by Wiley-VCH Verlag GmbH, Weinheim (2017).
3) J. S. Wilkes, J. A. Levisky, R. A. Wilson and C. L. Hussey: Inorg. Chem., 21 (1982), 1263-1264.

4) C. L. Hussey: Advances in Molten Salt Chemistry, Vol. 5, ed. by G. Mamantov, Elsevier, New York, (1983),185-230.

5) C. L. Hussey: Chemistry of Nonaqueous Solutions, Current Progress, ed. by G. Mamantov and A. I. Popov, VCH Publisher, New York, (1994), 227-275.

6) R. T. Carlin and J. S. Wilkes: Chemistry of Nonaqueous Solutions, Current Progress, ed. by G. Mamantov and A. I. Popov, VCH Publisher, New York, (1994), 277-306.

7) S. Takahashi, N. Koura, S. Kohara, M. L. Saboungi and L. A. Curtiss: Plasmas \& Ions, 2 (1999), 91-105.

8) M. Ueda: J. Solid State Electrochem., 21 (2017), 641-647.

9) T. Tsuda, G. R. Stafford and C. L. Hussey: J. Electrochem. Soc., 164 (2017), H5007-H5017, and references therein.

10) A. Endo, M. Miyake and T. Hirato: Electrochim. Acta, 137 (2014), 470-475.

11) Y. Fang, K. Yoshii, X. Jiang, X.-G. Sun, T. Tsuda, N. Mehio and S. Dai: Electrochim. Acta, 160 (2015), 82-88.

12) M. Paunovic and M. Schlesinger: Fundamentals of Electrochemical Deposition, John Wiley \& Sons, New York, NY, (1998), 250.

13) B. Li, C. Fan, Y. Chen, J. Lou and L. Yan: Electrochim. Acta, 56 (2011), 5478-5482.

14) A. Bakkar and V. Neubert: Electrochim. Acta, 103 (2013), 211-218.

15）高橋節子, 赤間良三, 倉沢 章, 奥佳代子：日新製鋼技報, 63 (1990), 44-51.

16) 高橋節子：電気化学, 59 (1991), 14-21.

17）春山志郎：表面技術者のための電気化学, 丸善, (2001).

18）高橋久留美, 行方千賀, 菊地竜也, 松島永佳, 上田幹人: 表面 技術，68（2017），208-212.

19）高橋節子，秋元菊子，佐伯 功：表面技術，40（1989），134135.

20) Q. Liao, W. R. Pitner, G. Stewart and C. L. Hussey: J. Electrochem. Soc., 144 (1997), 936-943.

21) T. Tsuda, T. Nohira and Y. Ito: Electrochim. Acta, 46 (2001), 18911897.

22）小浦延幸, 松本 太, 田代洋介, 二村昌樹, 井手本康: 表面技 術, 52 (2001), 791-792.

23）宇井幸一, 八代高士, 二村昌樹, 井手本康, 小浦延幸：表面技 術, 55 (2004), 409-416.

24) T. P. Moffat: J. Electrochem. Soc., 141 (1994), L115-L117.

25) M. R. Ali, A. Nishikata and T. Tsuru: Electrochim. Acta, 42 (1997), 2347-2354.

26) G. R. Stafford: J. Electrochem. Soc., 136 (1989), 635-639.

27) T. P. Moffat, G. R. Stafford and D. E. Hall: J. Electrochem. Soc., 140 (1993), 2779-2786.

28) T. Tsuda, C. L. Hussey, G. R. Stafford and J. E. Bonevich: J. Electrochem. Soc., 150 (2003), C234-C243.

29) T. Tsuda and C. L. Hussey: J. Min. Met., 39 (1-2)B (2003), 3-22.

30) T. Tsuda, S. Kuwabata, G. R. Stafford and C. L. Hussey: J. Solid State Electrochem., 17 (2013), 409-417.

31) T. Tsuda, Y. Ikeda, T. Arimura, M. Hirogaki, A. Imanishi, S. Kuwabata, G. R. Stafford and C. L. Hussey: J. Electrochem. Soc., 161 (2014), D405-D412.

32) T. Tsuda, C. L. Hussey, G. R. Stafford and O. Kongstein: J. Electrochem. Soc., 151 (2004), C447-C454.

33) T. Tsuda, Y. Ikeda, A. Imanishi, S. Kusumoto, S. Kuwabata, R. Gery Stafford and C. L. Hussey: J. Electrochem. Soc., 162 (2015), D405D411.

34) T. Tsuda, S. Arimoto, S. Kuwabata and C. L. Hussey: J. Electrochem. Soc., 155 (2008), D256-D262.

35) S.-J. Pan, W.-T. Tsai, J.-K. Chang and I.-W. Sun: Electrochim. Acta, 55 (2010), 2158-2162.

36) M. Miyake, H. Fujii and T. Hirato: Surf. Coat. Tech., 277 (2015), 160-164.

37) S. Shiomi, M. Miyake and T. Hirato: J. Electrochem. Soc., 159 (2012), D225-D229.

38) M. Ueda, T. Teshima, H. Matsushima and T. Ohtsuka: J. Solid State Electrochem., 19 (2015), 3485-3489. 
39) M. Ueda, H. Hayashi and T. Ohtsuka: Surf. Coat. Tech., 205 (2011), 4401-4403.

40) M. Ueda, R. Inaba and T. Ohtsuka: Electrochim. Acta, 100 (2013), 281-284.

41) K. Sato, H. Matsushima and M. Ueda: J. Appl. Surf. Sci., 388 (2016), 794-798.

42) M. Matsunaga, M. Morimitsu, M. Nagano and T. Tsuda: Molten Salt Chemistry and Technology, 5 (1998), 601

43) M. Ueda, D. Susukida, S. Konda and T. Ohtsuka: Surf. Coat. Tech., 176 (2004), 202-208.

44) G. R. Stafford: J. Electrochem. Soc., 141 (1994), 945-953.

45）内田淳一，瀬戸宏久，渋谷敦義：表面技術，46（1995），11671172

46) 内田淳一, 渋谷敦義, 津田哲郎, 山本康博, 瀬戸宏久：表面技 術, 42 (1991), 200-205

47) M. Ueda, H. Kigawa and T. Ohtsuka: Electrochim. Acta, 52 (2007), 2515-2519.

48) 岡本篤志, 森田昌行，吉本信子：表面技術，63（2012），641645.

49) 岡本篤志, 丹羽直敏, 江頭 港, 森田昌行, 吉本信子： Electrochemistry, 81 (2013), 906-911.

50) M. B. Pomfret, D. J. Brown, A. Epshteyn, A. P. Purdy and J. C. Owrutsky: Chem. Mater., 20 (2008), 5945-5947.

51) E. Perre, L. Nyholm, T. Gustafsson, P. L. Taberna, P. Simon and K. Edström: Electrochem. Commun., 10 (2008), 1467-1470.
52) G. Oltean, L. Nyholm and K. Edström: Electrochim. Acta, 56 (2011), 3203-3208.

53) S. Z. El Abedin, A. Garsuch and F. Endres: Aust. J. Chem., 65 (2012), $1529-1533$

54) S. Zein El Abedin and F. Endres: ChemPhysChem, 13 (2012), 250255

55) C. J. Su, Y. T. Hsieh, C. C. Chen and I. W. Sun: Electrochem. Commun., 34 (2013), 170-173.

56) C. J. Su and I. W. Sun: ECS Electrochem. Lett., 4 (2015), D21-D23.

57) L. H. S. Gasparotto, A. Prowald, N. Borisenko, S. Z. El Abedin, A. Garsuch and F. Endres: J. Power Sources, 196 (2011), 2879-2883.

58) 西村淳一, 奥野一樹, 木村弘太郎, 後藤健吾, 境田英彰, 細 江晃久, 吉川竜一：SEIテクニカルレビュー, 182 (2013), 34-38.

59）境田英彰，後藤健吾，木村弘太郎，奥野一樹，西村淳一，細江 晃久：SEIテクニカルレビュー, 190 (2017), 78-83.

60) S. K. Kim and R. G. Reddy: J. Korean Inst. Surf. Eng., 34 (2001), 553-567.

61) M. Zhang, V. Kamavarum and R. G. Reddy: JOM, 55 (2003), 54-57.

62) V. Kamavaram, D. Mantha and R. G. Reddy: Electrochim. Acta, 50 (2005), 3286-3295.

63) D. Pradhan, D. Mantha and R. G. Reddy: Electrochim. Acta, 54 (2009), 6661-6667.

64) 軽金属学会 研究委員会 新機能発現・化学プロセス部会 : 研究 部会報告書No. 61, 軽金属学会, (2015)，22-27. 